\title{
Rapid retrograde transport of proteins in sensory neurons in rats
}

\author{
DAVID J. FINK, DAVID PURKISS and MARINA MATA \\ Neurology Research Laboratory, University of Michigan and VA Medical Center, Ann Arbor, MI (U.S.A.)
}

(Accepted May 29th, 1985)

Key words: retrograde transport - N-succinimidyl $\left[2,3-{ }^{3} \mathrm{H}\right]$ propionate - sensory neuron - rat

\begin{abstract}
Twenty-four hours following the injection of $\mathrm{N}$-succinimidyl[2,3-3 $\mathrm{H}$ propionate into rat sciatic nerve, labeled protein appeared in the ipsilateral dorsal root ganglia. Autoradiography showed that the labeled proteins were found only in neuronal cell bodies. Gel electrophoresis showed a distinct pattern of rapidly retrogradely transported proteins were accumulating in the $D R G$ cells. This is the first demonstration of the rapid retrograde transport of endogenous axonal proteins in mammalian peripheral nerve.
\end{abstract}

In normal neuronal function, substances are transported within the axon both from the cell body towards the nerve terminal in a process known as anterograde axonal transport, as well as from the axon back towards the cell body in a process known as retrograde transport. The former serves to supply the axon with the structural and functional macromolecules necessary for continued axonal function. The latter consists both of endogenous neuronal constituents which were initially transported from the cell body and which then 'turnaround' within the axons or at the nerve terminal, as well as extrinsic macromolecules which are taken up at the nerve terminal and subsequently transported back towards the cell body 8,12 .

We have developed $\mathrm{N}$-succinimidyl[2,3-3 $\mathrm{H}]$ propionate $\left(\left[{ }^{3} \mathrm{H}\right] \mathrm{NSP}\right)$ to label endogenous axonal proteins in order to study their subsequent bidirectional translocation within the axon. Using that technique we have been able to label rapid anterograde transport from the hypothalamus to the pituitary in the rat $^{5}$, slow anterograde transport within the sciatic nerve of the rat and slow retrograde transport in rat sciatic nerve 6 . However, we have previously been unable to identify rapidly transported components within the peripheral nerve moving either anterogradely or retrogradely from the injection site, presum- ably because of the relatively small amount of material which is transported rapidly. Rapid retrograde transport is of particular interest because neuronal reactions to axonal injury occur over a time-course which suggests that a biochemical signal involved in normal nerve homeostasis and in the response to injury may move in rapid retrograde transport 3,9 and because of the recent demonstration that profound alterations in rapid retrograde transport may be an early alteration in toxic and metabolic neuropathies ${ }^{11,13}$.

In the hypothalamic-pituitary system rapid transport could be studied because the pituitary serves as a convenient source of axonal terminals where the rapidly transported components accumulate. In the current study we have used [ $\left.{ }^{3} \mathrm{H}\right] \mathrm{NSP}$ to identify the endogenous axonal constituents of rapid retrograde transport in the sensory neurons of the rat sciatic nerve by studying the accumulation of labeled proteins in the dorsal root ganglion (DRG) cells following the intraneural injection of $\left[{ }^{3} \mathrm{H}\right] \mathrm{NSP}$.

All experiments were performed on male SpragueDawley rats, 200-275 g. The animals were anesthetized with chloral hydrate and $1 \mu$ l of saline containing $100 \mu \mathrm{Ci}$ of [ ${ }^{3} \mathrm{H}$ ] NSP was injected subepineurially in the sciatic nerve as described previously6. At various times after injection the animals were killed

Correspondence: D. Fink, Neurology (127), VA Medical Center, 2215 Fuller Road, Ann Arbor, MI 48105, U.S.A. 
by intracardiac perfusion with $0.1 \mathrm{M}$ phosphate buffer and the DRGs processed as described below.

For protein analysis the L4, L5 and L6 DRGs from each side were pooled, suspended in $50 \mu \mathrm{l}$ of $5 \mathrm{mM}$

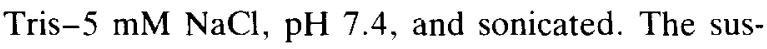
pension was precipitated with $10 \%$ trichloroacetic acid (TCA) and washed twice with acetone and twice with ether. The pellet was resuspended in $50 \mu \mathrm{l}$ of a solution containing $5 \%$ sodium dodecyl sulfate (SDS)-5\% beta mercapto ethanol (BME)-9 M urea-0.05 M Tris at $\mathrm{pH} 6.8$, heated at $100{ }^{\circ} \mathrm{C}$ for 3 $\mathrm{min}$ and an aliquot taken for determination of radioactivity. The sample was then run on a $5 \%$ to $18 \%$ gradient polyacrylamide slab gel, using the buffer system described by Laemmli10, prepared for fluorography with EnHance (New England Nuclear) and exposed to Kodak XAR film at $-70^{\circ} \mathrm{C}$, preflashed to an OD of 0.1 .
For autoradiography the animal was perfused through the heart with a $0.1 \mathrm{M}$ phosphate buffer, $\mathrm{pH}$ 7.4 , followed by $3 \%$ glutaraldehyde- $0.5 \%$ paraformaldehyde, and the DRGs removed. The tissue was washed in phosphate buffer, postfixed in $2 \%$ $\mathrm{OsO}_{4}$, dehydrated in ethanol and embedded in a Polybed-Araldite mixture. Semithin $(1 \mu \mathrm{m})$ sections were coated with Kodak D-19 and developed.

Autoradiography of the DRG at $24 \mathrm{~h}$ or 5 days after injection shows a dense accumulation of radioactive grains in DRG neurons exclusively (Fig. 1). Silver grains are found only in the ipsilateral DRG (Fig. $1 \mathrm{~A}, \mathrm{~B}, \mathrm{D})$, with no significant labeling of the contralateral DRG (Fig. 1C). Virtually no grains are found in the capsule of DRG. A few grains are seen in the axons passing through the DRG.

The amount of TCA precipitable radioactivity found in the ganglia was variable. However, in all an-
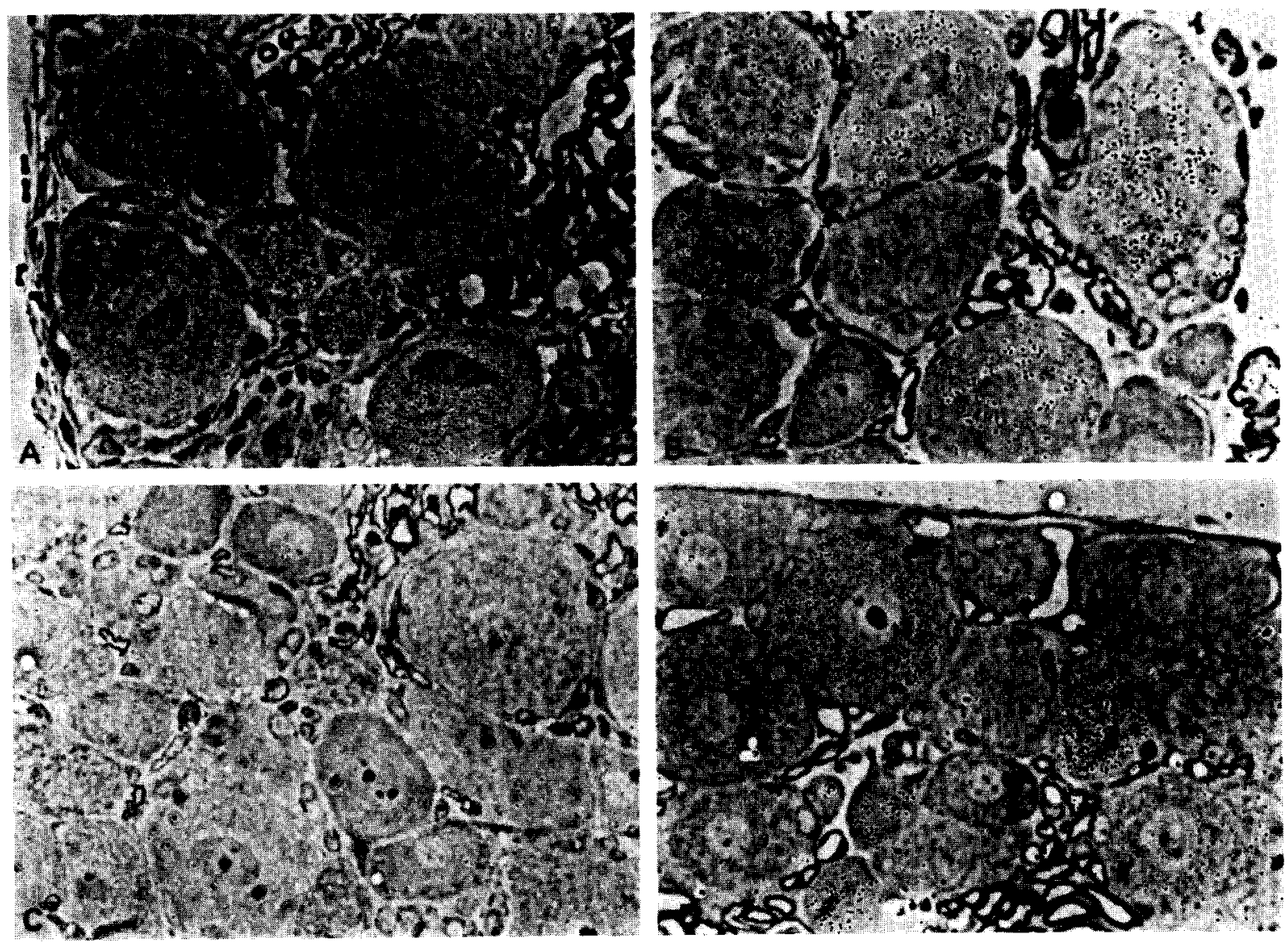

Fig. 1. Light microscopic autoradiography of DRGs 1 day (A, B, ipsilateral to injection; C, contralateral to injection) and 5 days (D, ipsilateral to injection) following the intraneural injection of $\left[{ }^{3} \mathrm{H}\right] \mathrm{NSP} . \mathrm{A}, \times 790,5$-week exposure; $\mathrm{B}, \times 840,5$-week exposure; $\mathrm{C}$. $\times 700,8$-week exposure; $\mathrm{D}, \times 700,12$-week exposure. 


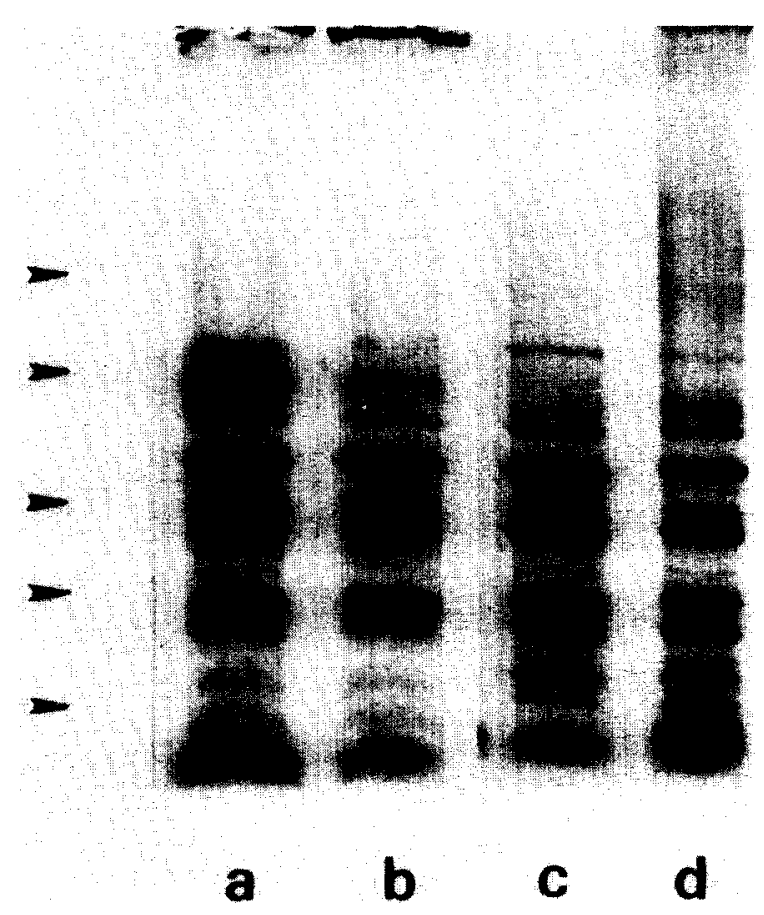

Fig. 2. Fluorograph of labeled proteins in ipsilateral DRGs $24 \mathrm{~h}$ (a and b), 4 days (c) and 7 days (d) after intraneural injection of $\left[{ }^{3} \mathrm{H}\right.$ ]NSP. The molecular weight standards (arrowheads) are $92,68,45,31$ and 21 kdalton, $a$ and b each contain the pooled protein from two animals. Each lane is from an independent gel run.

imals sacrificed $6 \mathrm{~h}$ to 7 days after $\left[{ }^{3} \mathrm{H}\right] \mathrm{NSP}$ injection, the ipsilateral DRG contained significantly more TCA precipitable counts than the contralateral DRG $(\mathrm{n}=28)$. In 4 control animals, the nerve was crushed between the injection site and the DRG just prior to the injection of $\left[{ }^{3} \mathrm{H}\right] \mathrm{NSP}$. In none of these animals was there significant radioactivity in the ipsilateral DRG, and in two the contralateral DRG had more counts than the ipsilateral DRG.

The SDS polyacrylamide gel electrophoresis (SDS-PAGE) analysis of labeled proteins in the dorsal root ganglia at $24 \mathrm{~h}, 4$ days and 7 days after injection shows that most of the labeled bands are seen in each of the time points (Fig. 2) and constitute a distinctive constellation of labeled proteins. Although fluorography is not quantitative, it appears that the relative amounts of some of the proteins may change over time. A variable amount of labeled polypeptide with a molecular weight of 68 kdalton appeared in some but not all of the 24-h animals, but was never present at later time points (cf. Fig. 2a, b). The reason for this variation at the early time points is not clear.
In this system the distance from the injection site to the dorsal root ganglia ranged from 40 to $60 \mathrm{~mm}$. Therefore the transport rate of the labeled proteins should be in excess of $40 \mathrm{~mm} / \mathrm{day}$, and the appearance by $6 \mathrm{~h}$ of specific ipsilateral radioactivity suggests that some components are being transported in excess of $160 \mathrm{~mm} /$ day.

The pattern of proteins accumulating in the DRG is different from those proteins which are transported in the retrograde direction slowly $(3-5 \mathrm{~mm} /$ day) within the sciatic nerve 7 . It also is clearly distinct from the pattern of slow anterograde transport in the nerve demonstrated either with conventional pulse labeling techniques or following the intraneural injection of $\left[{ }^{3} \mathrm{H}\right] \mathrm{NSP}$. There are certain similarities in the one-dimensional gel analysis between the pattern of retrograde transport and the pattern seen in the nerve anterograde from the injection site two days after $\left[{ }^{3} \mathrm{H}\right] \mathrm{NSP}$ injection, but whether the retrogradely transported proteins represent the turnaround transport of anterogradely transported labeled proteins will require two-dimensional gel analysis. There are also some similarities in the one-dimensional gel analysis between the rapidly retrogradely transported proteins demonstrated in the DRG neurons and those demonstrated to be retrogradely transported from the optic nerve to the retina of the goldfish 15 .

Bisby has demonstrated the retrograde 'turnaround' transport of axonal proteins which are labeled at the cell body and transported towards the terminal by rapid anterograde transport ${ }^{1,2}$. More recently, the retrograde transport of antibodies to synaptic membrane proteins in the hypoglossal and facial nerves and the specific retrograde (but not anterograde) transport of antibodies to membrane glycoproteins in the rat central nervous system have been demonstrated ${ }^{4} .14$. The $\left[{ }^{3} \mathrm{H}\right] \mathrm{NSP}$ labeled retrogradely transported proteins are another class of endogenous axonal proteins which are transported back to the cell body at relatively rapid rates. Some of these proteins may serve a role in normal neuronal function and in signalling axonal injury.

This work was supported by VA Merit Review Grants to D.J.F. and M.M. We wish to acknowledge the excellent technical assistance of Julie Staple in histology and autoradiography. 
1 Bisby, M. A., Functions of retrograde axonal transport, Fed. Proc., 41 (1982) 2307-2311.

2 Bisby, M. A., Reversal of axonal transport: similarity of proteins transported in anterograde and retrograde directions, J. Neurochem., 36 (1981) 741-745.

3 Cragg, B. G., What is the signal for chromatolysis?, Brain Research, 23 (1970) 1-21.

4 Fabian, R. H., Ritchie, T. C. and Coulter, J. D., Properties of axonally transported antibodies to rat brain fractions, Soc. Neurosci. Abstr., 14 (1984) 353.

5 Fink, D. J. and Gainer, H., The use of a labeled acylating probe for the study of fast axonal transport, in vivo, Brain Research, 177 (1979) 208-213.

6 Fink, D. J. and Gainer, H., Axonal transport of proteins. A new view using in vivo covalent labeling, J. Cell Biol., 85 (1980) 175-186.

7 Gainer, H. and Fink, D. J., Evidence for the slow retrograde transport of serum albumin in rat sciatic nerve, Brain Research, 233 (1982) 404-408.

8 Grafstein, B. and Forman, D. S., Intracellular transport in neurons, Physiol. Rev., 60 (1980) 1167-1283.

9 Kirstensson, K., Retrograde signaling after nerve injury. In
J. Elam and P. Cancalon (Eds.), Axonal Transport in Neuronal Growth and Regeneration, Plenum Press, New York, 1984, pp. 31-44.

10 Laemmli, U. K., Cleavage of structural protein during the assembly of the head of bacteriophage, Nature (Lond.), 227 (1970) 680-685.

11 Miller, M. S. and Spencer, P. S., Single doses of acrylamide reduce retrograde transport velocity, J. Neurochem., 43 (1984) 1401-1408.

12 Ochs, S., Axoplasmic Transport and Its Relation to Other Nerve Functions, John Wiley, New York, 1982.

13 Schmidt, R. E. and Modert, C. W., Orthograde, retrograde and turnaround axonal transport of dopamine beta hydroxylase: response to axonal injury, J. Neurochem., 43 (1984) 865-870.

14 Wenthold, R. J., Skaggs, K. K. and Reale, R. R., R.1: 9grade axonal transport of antibodies to synaptic membiane components, Brain Research, 304 (1984) 162-165.

15 Williams, L. R. and Agranoff, B. W., Retrograde transport of goldfish cystic nerve proteins labeled by $\mathrm{N}$-succinimidyl[ $\left.{ }^{3} \mathrm{H}\right]$ propionate, Brain Research, 259 (1983) 207-216. 